\title{
VOLCANOLOGICAL AND STRUCTURAL ASPECTS OF THE VENETIA KIMBERLITE CLUSTER
}

\author{
Stephan Kurszlaukis ${ }^{1}$ and Wayne Barnett ${ }^{2}$ \\ ${ }^{l}$ De Beers GeoScience Centre, South Africa; ${ }^{2}$ De Beers Venetia Mine, South Africa
}

\section{INTRODUCTION}

The Venetia kimberlite pipes are located within the Limpopo mobile belt, which is an ancient collision zone of the Kaapvaal and Zimbabwe craton. At the present erosion level the country rock in the Venetia area appears as a complex arrangement of gneisses, amphibolites and metasediments of the Limpopo Group. The basement rocks form a synclinal structure dipping east-west, with the kimberlites of the cluster located in the fold axis of the syncline. The country rock appears to comprise two main packages of rocks belonging to the Limpopo Group, i.e. a high metamorphic grade gneissic package (upper amphibolite facies) that dominates the core of the synclinal structure and a meta-sedimentary package which occurs in the outer limb enfolding the gneissic package in the syncline. Next to that a 25 to $60 \mathrm{~m}$ thick dolerite sill is intruded at a depth of about $250 \mathrm{~m}$ below present day surface. At least two phases of pegmatites also intruded the country rock.

The basement rocks appear to be tectonically juxtaposed by shearing with a structurally complex contact zone of cataclasite, hydrothermally altered schist and isoclinal folding in between. Hydrothermal alteration is most distinctly developed within faults and shear zones and also along joints in the dolerite sill, giving evidence to significant quantities of water that migrated along the faults in the geological past.

Grey and red shale as well as vesicular basalt xenoliths found in the kimberlite of the various pipes suggest that a sedimentary sequence, probably of the the $1.85 \mathrm{Ga}$ Soutpansberg Group overlaid the basement at the time of emplacement (Bumby et al., 2001 and references therein). It is, however, difficult to estimate the erosion rate since the time of emplacement of the pipes about 519 Ma years ago (Phillips et al., 1999), as it is not easy to link these xenoliths to the pre-existing stratigraphy of the Precambrian Waterberg Group.

The Venetia kimberlite cluster consists of 14 bodies that outcrop in an area of about four $\mathrm{km}^{2}$ (Fig. 1a) The largest and central body is "K1" which covered an area of about 12 ha at the pre-mining surface. K1 is kidneyshaped, about 650 by $200 \mathrm{~m}$ in size, and elongated eastwest. Most of the pipe is infilled by fragmental kimberlite, but localised hypabyssal kimberlite intrusions occur at the margins as well. A country rock breccia occurs in contact with $\mathrm{K} 1$ at the south-eastern margin and is delineated by prominent fractures at its western and eastern side (Fig. 1c). The breccia occupies a at least $150 \mathrm{~m}$ deep and $100 \mathrm{~m}$ wide space within the country rock. A highly increased number of country rock xenoliths within the pipe adjacent to the breccia testifies to the syngenetic relationship of the breccia with the pipe.

The second largest pipe of the cluster is K2, which occurs to the west of $\mathrm{K} 1$ and is separated from $\mathrm{K} 1$ by a thin country rock barrier of about $200 \mathrm{~m}$ thickness. K2 is roughly oval in shape, with dimensions of about 250 x $200 \mathrm{~m}$ and covers an area of 5 ha at the present surface. Towards its western side $\mathrm{K} 2$ is occupied by a breccia that is very rich in country rock clasts. The central part of the pipe is filled by, "TKB", but at depth and especially towards the southern and western margin hypabyssal kimberlite is present.

\section{STRUCTURAL GEOLOGY AND PIPE SHAPES}

Pipe shapes appear highly variable. In plan they include spherical, and oval to irregular shapes. In general, the pipes seem to be elongated into WNW-ESE or NE-SW directions (Fig. 1a-c). One of the most irregular pipes in the cluster is also the largest one (K1). The infill of K1 seems to consist of at least two major units, one occupying the eastern and one the western part of the pipe ("TKB East" and "TKB West"; Seggie et al., 1999). Recent petrographic work conducted by Skinner (pers. comm., 2000) suggests a more complicated picture with at least three different units of fragmental kimberlites. At $400 \mathrm{~m}$ depth there is still no indication that the pipe splits into separate roots, which would be one of the possible explanations for the complex pipe shape, the multitude of volcanic units and the variations in diamond grade.

The complex shape of K1 seems to be controlled by the country rock structure. K1 is generally east-west elongated, but has its highest degree of irregularity at its eastern end, where it is extended towards the north-east. It is in this region that the Lezel shear zone strikes towards the north-east. A splay of this fault passes directly through the centre of the north-east extension of K1 (Fig. 1c). The general east-west elongation correlates closely with the east-north-east strike of a joint set which is developed in the country rock west of 

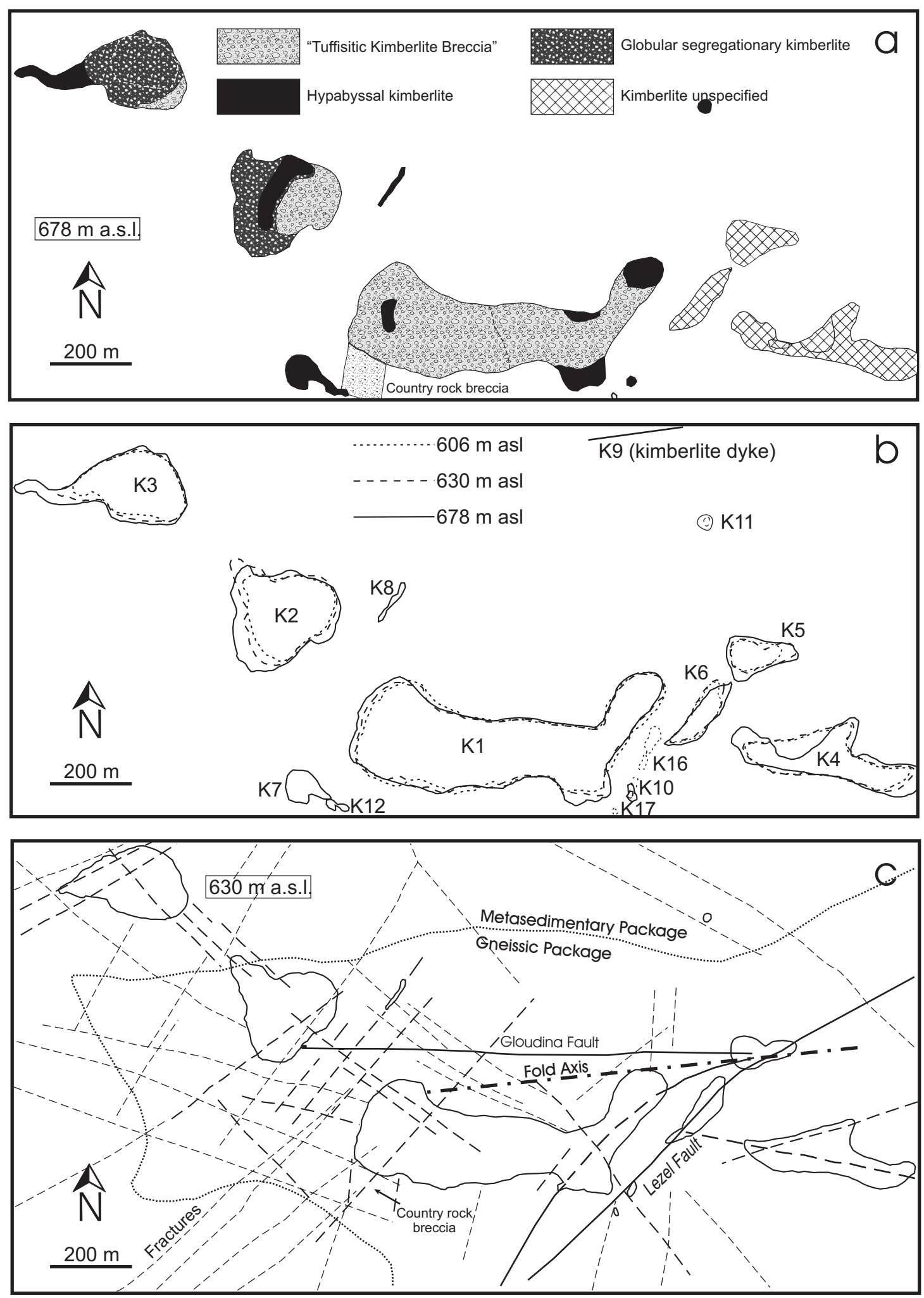

Figure 1a-c: The surface outlines (678 m asl), pipe positions and a simplified map of the internal geology of the pipes and dykes of the Venetia kimberlite cluster (modified after Seggie et al., 1999, Colgan (pers. comm.) and Skinner (pers. comm.)) is shown in Fig. 1a. The pipe outlines at $678 \mathrm{~m}$ (surface), $630 \mathrm{~m}$ and $606 \mathrm{~m}$ asl are highlighted in Fig. 1b. The most important faults, shear zones and joint sets in the Venetia area together with the pipe outlines at $630 \mathrm{~m}$ asl are shown in Fig. 1c. From: Kurszlaukis and Barnett, 2003. 
K1. The Lezel fault clips the south-eastern corner of K1 and then passes east of the main kimberlite body.

The pipe outline of K1 seems to be controlled not only by pre-existing faults within the country rocks, but also by the stratigraphy of the adjacent basement lithologies. The folded stratigraphic layering plunges eastwards at about $31^{\circ}$. The western K1 boundary also dips eastwards at a relatively shallow angle apparently following the country rock layering closely in places.

A number of small kimberlite bodies and dykes have intruded along the Lezel fault plane. From the south the K1 pipe has a hypabyssal intrusion extending southwards between the two splays of the fault zone. Further east are the K17 and K10 dyke-shaped bodies. $\mathrm{K} 10$ is clearly emplaced on the Lezel fault, is strongly sheared by a re-activated movement on the fault, and is highly altered due to groundwater flowing along the fault. North of K10 is K16, which strikes northwards away from the fault plane, possibly along the $\mathrm{J} 1$ joint sets. Both K16 and K17 are kimberlite bodies that do not extend to the present surface. North of K16 is K6, which is clearly elongated along the strike of the Lezel fault plane. The northern tip of K6 intersects the synclinal basement fold axis with the contact edges being strongly controlled by the folded metamorphic layering as it intrudes partially along the axis. K6 elongates north-eastwards and coalesces with $\mathrm{K} 5$ at depth. Near the surface K5 is a wider, irregular kimberlite body that is partially elongated towards the east-north-east. K5 appears to be on the intersection area of the two NE trending fault splays and the westnorth-west striking Gloudina fault. Approximately $20 \mathrm{~m}$ of the eastern edge of the K5 kimberlite is strongly sheared, again showing that the faults have been reactivated. Exploration drillholes indicate that dykes, which intruded along the Lezel fault plane, connect K17, K10, K16, K6 and K5 at depth.

$\mathrm{K} 4$ is a very irregularly-shaped kimberlite pipe that extends strongly along an east-south-east trend away from K6. Protrusions appear to extend along north-east striking joint sets away from the main body, but the overall shape is likely to be controlled by a west-northwest trending fault. A drillhole situated east of K4 was intended to intersect such a fault. The drillhole did intersect strongly sheared gneisses and schists and yielded significant groundwater.

A set of joints strike north-westwards from K1 intersecting $\mathrm{K} 2$ and then $\mathrm{K} 3$ along the same trend. $\mathrm{K} 2$ is an internally complex pipe that appears to be divided into a distinct eastern and a western half. The eastern side has been documented as a "TKB" facies and the western half as a hypabyssal breccia facies with a transitional segregationary textured kimberlite at the contact between the halves (Fig. 1a; Seggie et al., 1999;
Skinner, pers. comm. 2000). However, investigations in the open pit and of drill cores reveal a crudely bedded nature of the "TKB" infill. K2 is placed on the intersection of a strong north-east trending fracture/fault set and the north-west striking joints. In addition, there is an eastward striking fault clearly visible on the southeastern edge of the pipe. This fault has caused the irregular shape on the south-eastern corner. A distinct extension of the K2 pipe expands north-westwards towards K3, obviously following the north-weststriking joints. The extension is filled with country rock breccia and being nearly non-existent at surface it increases in size towards the north-west with depth.

$\mathrm{K} 3$ occurs at the end of the north-west trending joint set as a very irregular pipe outcropping at surface with a protrusion extending towards the west. This protrusion appears to shorten and narrow towards depth, although more detailed exploratory drilling is required to confirm this. The overall east-west alignment of the protrusion is the result of two trends, a north-east trend where a prominent north-east striking fracture intersects $\mathrm{K} 3$, and a joint controlled side-step of the protrusion towards the north-west. The position of K3 is coincident with the intersection of the north-east fracture and the northwest trending joints.

$\mathrm{K} 8$ is an unusual hypabyssal breccia pipe with a strong north-north-east alignment since it lies along northnorth-east trending fractures. The full geometry of the pipe is not known at this stage but it is clear that the K8 kimberlite is surrounded by a wide (perhaps as much as 20-30 m) and irregular envelope of country rock breccia. Very little is known about the K11 kimberlite found north-north-east of K1. Pipes K7 and K12 appear as separate bodies at the present surface, but about $20 \mathrm{~m}$ below the surface they merge into one body that is elongated towards the north-west, again following a north-west trending fracture or fault. This same fault forms the southern contact of a prominent rectangular body of country rock breccia that is found immediately east of K12 and extends northwards into the K1 pipe. The eastern and western edges of this breccia body are extremely sharp and defined by south-south-west striking J1 fractures. The K12 and K7 bodies have not yet been modelled to the depths indicated in Fig. $1 \mathrm{~b}$ and -c.

The above observations highlight the importance of the influence of the following structures on the Venetia pipes positions and shapes: [1] north-west striking minor faults, fractures and joints (including J6), [2] north-east striking faults and joints (J2), and [3] northsouth to north-north-east striking joints (J1). As mentioned above, J1 appear to be formed as tension fractures in en-echelon envelopes that imply northsouth compression. Following this model through 
implies dextral re-activation of north-west striking fractures and minor-faults, and sinistral re-activation of north-east striking faults (proof for which is observed in the rock). Such north-south compression would produce dilational jog (local extension) on the Lezel fault in the exact area of the eastern $\mathrm{K} 1$ pipe. A swing in the direction of compression towards the north-west at the time of kimberlite emplacement would open up the north-west fractures and faults allowing the migration of kimberlite to the surface (M. Watkeys, pers. comm., 2002). The actual growth of the kimberlite pipe shape during volcanism would then be governed by jointcontrolled tensional failure and slumping of the pipe sidewalls.

\section{Internal geology of the pipes}

The Venetia kimberlite pipes have previously been regarded as typical southern African pipes, i.e. they are large and presumably deep pipes occupied by a fragmental rock which had been termed "Tuffisitic Kimberlite Breccia", or "TKB". The origin of this rock had been thought to be intrusive, and by that it should be unbedded and massive in nature.

Although the "TKB" in K1 was described as homogeneous in appearance, Colgan (De Beers internal report, 1981) noticed localised zones of higher country rock xenolith abundances and -sizes as well as localised "flow zones" of finer-grained "tuffisitic" kimberlite from relatively shallow drill cores (mostly $<200 \mathrm{~m}$ ). However, our drill core examinations reveal that proper (graded) bedding is present on a micro-, macro-, and megascale throughout the entire body of fragmental kimberlite down to a depth of $-430 \mathrm{~m}$ from the present land surface. In general, bedding seems to become less obvious towards depth and the beds become more massive, often up to several tens of metres thick with only thin, fine(er)-grained and partly reworked or primary pyroclastic tops. Although these bedded rocks are clearly of volcanogenic origin, they still classify as classical "TKB' $\mathrm{s}$ " in thin section.

Bedding, signs of reworking in between and on top of the massive "TKB" layers, the presence of mud-clasts and quartz-rich layers within fine-grained and finebedded crater-facies rocks found as isolated blocks in the younger volcaniclastic kimberlite hosting them, as well as the presence of talus fans overlain by "TKB" suggest time spans of relative volcanic inactivity in between very violent activity phases. This suggests an emplacement over weeks, months or even years and clearly contradicts the presence of a single, highlyenergetic eruption.

Water was evidently present during emplacement of the Venetia kimberlite pipes. This is testified by the presence of accretionary (armoured) lapilli, possible lake beds, soft sediment deformation textures and cross bedding observed in the reworked, fine-grained layers overlying massive beds. Isolated crater-facies blocks with unknown genetic relationship to the hosting volcaniclastic rocks clearly show bedding (lamination), sorting, the presence of mud clasts and soft sediment deformation textures. All these features suggest a high moisture content of the volcaniclastic sediments during and after emplacement and possibly even free flowing water on the crater floor.

Collapse structures as seen in the slump breccias at the south-west side of $\mathrm{K} 1$ and within other contact breccias, sidewall oversteepening, a possible floating reef in $\mathrm{K} 4$, and the collapsed roof of a possible cavity at the northwest side of K2 all suggest a volume deficit in deeper levels of the pipe. The nature of these apparently slumped country rock breccias around most of the pipes and the evidence for their origin is being investigated in more detail by W. Barnett (Country Rock Slump Breccias in Kimberlite Pipes, $8^{\text {th }}$ IKC poster).

General problems are the different sizes and the different structural levels of the pipes within the same cluster of the same age at the same erosion level. At $\mathrm{K} 4$, a relatively small pipe, a contact breccia is present, which is rather typical for root zones or lower levels of a diatreme. This is also the case at $\mathrm{K} 8$, a xenolith-rich hypabyssal intrusion which is surrounded by an envelope of highly brecciated country rock, suggesting a root zone surrounded by its contact breccias. In contrast, bedded volcaniclastic kimberlite is present in adjacent $\mathrm{K} 1$, the largest pipe of the cluster, over $350 \mathrm{~m}$ deeper than the contact breccia in K4. At the same depth level, talus fans within K2 suggest sedimentation onto the crater floor which are overlain by "TKB"looking rocks.

A fundamental problem is the presence of petrographically identified "TKB"s. In thin section they fulfil all requirements for typical "TKB"s (Colgan, pers. comm.; Field and Scott Smith, 1999; Skinner, pers. comm. 2000, and own data), but they derive from bedded sequences and even overlie crater floor talus deposits in $\mathrm{K} 2$. We regard these rocks as volcaniclastic deposits and not as intrusive rocks.

A further open question is by which kind of process the volcaniclastic layers filling the pipes were formed. They are either pyroclastic or reworked epiclastic and may either be related to the same volcano into which they were deposited in or related to a neighbouring volcano in the same cluster. It is also not clear to what extent the diatreme was evacuated by a potentially ventclearing process, or whether the maar crater was relatively shallow and filled up by the renewed 
sedimentation of volcaniclastic material during ongoing subsidence (Lorenz, 1985, 1986).

The authors stress that the information provided in this paper is the state of knowledge at the time of submission of the manuscript. We are aware, that with the continuous mining of the pipes, more features relevant for developing an emplacement model will be discovered. However, our observations suggest that phreatomagmatic processes could have played a considerable role in the emplacement history of Venetia.

\section{REFERENCES}

Bumby, A.J., Eriksson, P.G., van der Merwe, R. and Maier, W.D., 2001. The stratigraphic relationship between the Waterberg and Soutpansberg Groups in Northern Province, South Africa: evidence from the Blouberg area. South African Journal of Geology, 104/3, 205216.

Field, M. and Scott Smith, B.H., 1999. Contrasting geology and near-surface emplacement of Kimberlite Pipes in Southern Africa and Canada. Proceedings of the $7^{\text {th }}$ International Kimberlite Conference, Cape Town, 1998. 214-237.

Kurszlaukis, S. and Barnett, W.P., 2003. Volcanological and structural aspects of the Venetia Kimberlite Cluster a case study of South African kimberlite maardiatreme volcanoes. South African Journal of Geology, in press.

Lorenz, V., 1985. Maars and diatremes of phreatomagmatic origin, a review. Transactions of the Geological Society of South Africa, 88, 459-470.
Lorenz, V., 1986. On the growth of maars and diatremes and its relevance to the formation of tuff-rings. Bulletin of Volcanology, 48, 265-274.

Phillips, D., Kiviets, G.B. Barton, E.S., Smith, C.B., Viljoen, K.S., and Fourie, L.F., 1999. ${ }^{40} \mathrm{Ar} /{ }^{39} \mathrm{Ar}$ dating of kimberlites and related rocks: problems and solution. Proceedings of the $7^{\text {th }}$ International Kimberlite Conference, Cape Town, 1998. 677-687.

Seggie, A.G., Hannweg, G.W., Colgan, E.A. and Smith, C.B., 1999. The geology and geochemistry of the Venetia kimberlite cluster, Northern Province, South Africa. Proceedings of the $7^{\text {th }}$ International Kimberlite Conference, Cape Town, South Africa, 750-756.

Contact: S. Kurszlaukis, PO Box 82232, Southdale, 2135, RSA, E-mail: stephan.kurszlaukis@debeersgroup.com
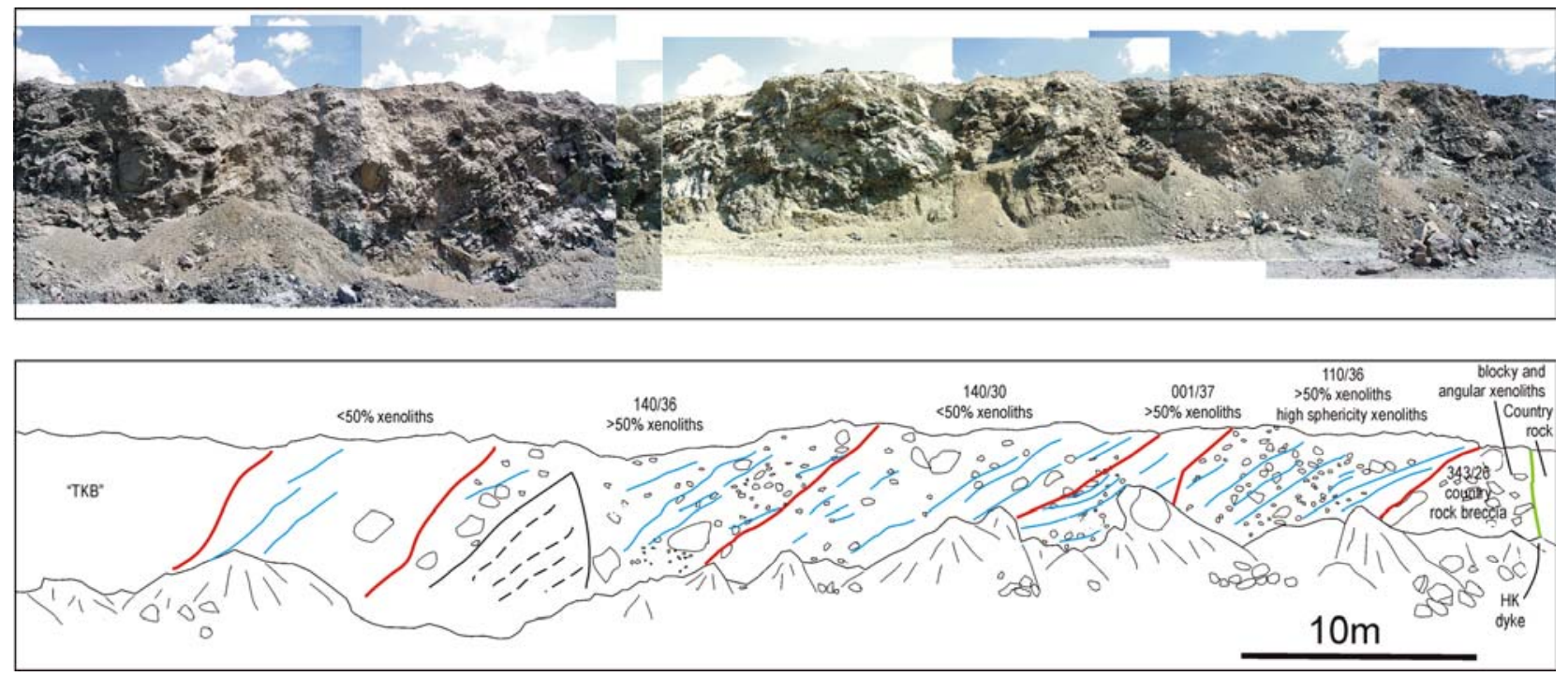

Figure 2: The set of photographs shows at least 5 different talus fans filling up pipe K2 from the western side contact. The talus fans are overlain by "TKB” (left). From: Kurszlaukis and Barnett, 2003. 